\title{
Combining bioenergy and nature conservation: An example in wetlands
}

\author{
Indrek Melts $^{\mathrm{a}, \mathrm{d}, *}$, Mari Ivask ${ }^{\mathrm{b}}$, Mohan Geetha ${ }^{\mathrm{c}}$, Kazuhiko Takeuchi ${ }^{\mathrm{d}, \mathrm{e}}$, Katrin Heinsoo ${ }^{\mathrm{a}}$ \\ ${ }^{a}$ Chair of Biodiversity and Nature Tourism, Estonian University of Life Sciences, Kreutzwaldi 5, 51006, Tartu, Estonia \\ ${ }^{\mathrm{b}}$ Tallinn University of Technology, Tartu College, Puiestee 78, 51008, Tartu, Estonia \\ ${ }^{\mathrm{c}}$ Institute for the Advanced Study of Sustainability, United Nations University, 5-53-70 Jingumae, Shibuya-ku, Tokyo, 150-8925, Japan \\ ${ }^{\mathrm{d}}$ Institute for Future Initiatives, The University of Tokyo, 7-3-1 Hongo, Bunkyo-ku, Tokyo, 113-0033, Japan \\ ${ }^{\mathrm{e}}$ Institute for Global Environmental Strategies, 2108-11 Kamiyamaguchi, Hayama, Kanagawa, 240-0115 Japan
}

\section{A R T I C L E I N F O}

\section{Keywords:}

Bioenergy

Ethanol

Floodplain meadow

Methane

Common reed

Reed canary grass

Wetland

Sustainable development

\begin{abstract}
A B S T R A C T
Conservation and restoration are crucial to maintaining a wide range of functions and services in wetlands, but it is difficult to find a reasonable and resource-efficient management option without sacrificing ecological values. In the present paper, we analyse the variability and dynamics of the chemical composition and energy potential of biomass from reedbeds, floodplain meadows, coastal meadows and reed canary grass cultivation in extracted peatlands. We observed that the chemical characteristics that are crucial for bioenergy production vary by biomass origin and over time. The bioenergy potential depends on biomass production and on the conversion method. The results indicate that the energy potential ranges from 122 to $190 \mathrm{GJ} /$ ha per year in semi-natural floodplain meadows in the boreal zone. About $160 \mathrm{GJ} /$ ha per year can be obtained from natural reedbeds but only about $120 \mathrm{GJ} /$ ha per year from cultivated extracted peatlands. Using methane conversion, we can obtain only about $50 \%$, and using ethanol conversion we can obtain less than $20 \%$ of the total energy potential of the herbaceous biomass of floodplain meadows. Although long-term studies on homo- and heterogeneous biomass production are required, we conclude that the local biomass of natural, semi-natural and artificial wetlands could contribute significantly to sustainable development.
\end{abstract}

\section{Introduction}

\subsection{Description of wetlands}

The Ramsar Convention defines wetlands as areas of marsh, fen, peatland or water, whether natural or artificial, permanent or temporary, with water that is static or flowing and either fresh, brackish or salt, including areas of marine water the depth of which at low tide does not exceed $6 \mathrm{~m}$ [1]. Wetlands include a broad range of various natural and artificial habitats with diverse species and plant communities, with and without a peat layer [2-7].

The main and most important peat-forming functional plant group with low productivity is the genus Sphagnum, which is distributed in northern, tropical and southern-hemisphere peatlands. The common reed (Pragmites australis) is a widely distributed (excepting Antarctica) grass species that grows in diverse wetland types [8-10]. The reed is a tall generalist that tolerates soils with diverse $\mathrm{pH}$, salinity, fertility and textures and usually forms dense monospecific stands as reedbeds or reedswamps $[6,7,10,11]$. Another globally distributed common perennial herbaceous and clonal plant species is cattail (Typha spp., family
Typhaceaea), which also forms dense stands in cattail marshes/swamps in natural wetlands $[6,7,12-14]$. Sedges (Carex spp.) and rushes (Juncus spp.) are also important and typical herbaceous plant genera in wetlands, where they usually take advantage of seasonal flooding, higher groundwater levels and the nutrient content of water [15-18]. Sedges can also form monospecific tall-sedge communities in sedge or wet meadows $[6,7,16,19]$. In wetlands (e.g., the freshwater tidal zone), the reed or tall-sedge belt is usually followed by reed canary grass (Phalaris arundinacea), a productive and dominative cool-season grass species in the boreal zone $[7,20,21]$. Such emergent plants make up the majority of wetland flora. In keeping with the focus of this study, these plant species can be separated into distinct groups. In grassland-production ecology studies (also herein), the plant species are often categorised into the following functional groups: grasses (monocotyledonous species of the family Poaceae), sedges and rushes (monocotyledonous species of the families Cyperaceae and Juncaceae), nitrogen-fixing legumes (dicotyledonous species of the family Fabaceae) and other dicotyledonous broad-leaf forbs [11,16-19].

\footnotetext{
* Corresponding author. Chair of Biodiversity and Nature Tourism, Estonian University of Life Sciences, Kreutzwaldi 5, 51006, Tartu, Estonia.

E-mail addresses: indrek.melts@gmail.com, indrek.melts@emu.ee (I. Melts).
} 


\begin{tabular}{|llll|}
\hline \multicolumn{2}{|l|}{ Nomenclature } & $\mathrm{Kg}$ & Kilogram \\
$\mathrm{C}$ & Carbon & $\mathrm{Mg}$ & Magnesium \\
$\mathrm{Ca}$ & Calcium & $\mathrm{MJ}$ & Megajoules, $0^{6} \mathrm{~J}$ \\
$\mathrm{CH}_{4}$ & Methane & $\mathrm{m}^{3}$ & Cubic mere \\
$\mathrm{C}_{2} \mathrm{H}_{5} \mathrm{OH}$ & Ethanol & $\mathrm{N}$ & Nitrogen \\
$\mathrm{Cl}$ & Chlorine & $\mathrm{P}$ & Phosphorus \\
$\mathrm{CV}$ & Calorific value & $\mathrm{pH}$ & hydrogen-ion activity (acidity or alkalinity) \\
$\mathrm{DM}$ & Dry matter & $\mathrm{PHA}$ & polyhydroxyalkanoate \\
$\mathrm{GJ}$ & Gigajoules, $10^{3} \mathrm{~J}$ & $\mathrm{~S}$ & Sulfur \\
ha & Hectares & $\mathrm{T}$ & Tonne \\
$\mathrm{K}$ & Potassium & $\mathrm{VS}$ & Volatile solids \\
\end{tabular}

\subsection{The value of wetland ecosystems}

Wetlands are important ecosystems, and many are protected at the European level or worldwide [1,22]. They provide diverse important functions and services [23]. Historically, wetlands have been important as sources of food, feed supply, raw materials and medicines for human beings; as habitats for a wide variety of flora and fauna, including endangered species; as valuable freshwater/groundwater reservoirs that improve water quality; as buffer zones for flood control or shoreline and storm protection; for enabling nutrient exchange between alluvial sediments and the atmosphere; as carbon-accumulation pools; as providers of cultural values and recreational options; and for mitigation and adaptation during climate change [2,5,6,23-28].

Over the past century, the area of natural wetlands in the world has decreased considerably due to land-use changes (e.g., melioration, agricultural intensification, the draining of wetlands, etc.) [23,29-35]. Human impact, leading to habitat loss and fragmentation, poses a threat to plant species populations and causes a decline in plant species richness $[8,11,16,30,36-39]$. This degradation and loss of biological diversity will alter the functioning of ecosystems and their ability to provide society with goods and services [23,40-43]. Therefore, it is important to manage existing wetlands with sustainable methods to maintain and develop these ecosystem services and functions and to restore potential ones with the appropriate and most effective technology [6,14,31,44-49].

Much information is available on the use of grassland biomass for diverse bioenergy options, but a review and comparison of diverse wetland types and the suitability of their biomass for bio-based products is still lacking. Therefore, the current study primarily aimed to assess and compare the composition and potential of the biomass of diverse boreal wetland types (alluvial/floodplain meadows, coastal meadows, reedbeds and cultivated extracted peatlands) for various bioenergy technologies. The study proposed the following hypotheses: (i) Biomass production differs by wetland type; (ii) the crucial characteristics of wetland biomass for diverse bioenergy conversion options vary by origin and by time of harvest; (iii) the potential for methane production differs by the origin of wetland biomass; and (iv) energy output will depend on the wetland type and on the energy carriers in various conversion methods.

\section{Biomass production in wetlands}

\subsection{Biomass production of diverse wetland and abiotic factors}

Wetlands are ecosystems with a very wide range of yields, reaching a maximum of up to about $40 \mathrm{t} / \mathrm{ha}$ for swamps and marshes $[3,7,50]$. Actual biomass production is subject to various abiotic conditions related mainly to geographical latitude parameters and the availability of water and nutrients in the substrate $[7,51,52]$. It has been demonstrated that the functional traits of common reed (Phragmites australis) production vary across the geographic gradient [53] In the boreal zone, the common reed produces up to $10 \mathrm{t} / \mathrm{ha}[11,54,55]$, but in warmer

Table 1

Description of different wetlands based on disturbance level (natural, semi-natural and artificial) and their biomass yield ( $\mathrm{t} / \mathrm{ha}$ ).

\begin{tabular}{|c|c|c|c|c|c|c|}
\hline No & Type & Country & Dominant species & Management & Yield & References \\
\hline 1 & Coastal meadow & Estonia & Phragmites australis & Natural, no management & 6.5 & [11] \\
\hline 2 & Tall sedge swamp & Germany & $\begin{array}{l}\text { Carex acutiformis, } \\
\text { Cirsium arvense etc. }\end{array}$ & Natural, no management & 6.7 & {$[51]$} \\
\hline 3 & Reedbed/swamp & Estonia & Phragmites australis & Natural, no management & 8.6 & {$[54]$} \\
\hline 4 & Reedbed/swamp & Sweden & Phragmites australis & Natural, no management & 10.0 & {$[55]$} \\
\hline 5 & Floodplain meadow & Estonia & Carex acuta & Natural, no management & 11.2 & [16] \\
\hline 6 & Floodplain meadow & Estonia & Filipendula ulmaria & Natural, no management & 12.8 & [16] \\
\hline 7 & Brackish tidal marsh & USA & Phragmites australis & Natural, no management & 18.6 & [56] \\
\hline 8 & Floodplain meadow & USA & $\begin{array}{l}\text { Carex aquatilis, } \\
\text { Carex utriculata etc. }\end{array}$ & Natural, previous grazing, live + dead biomass & 22.4 & {$[52]$} \\
\hline 9 & Reedbed/swamp & China & Phragmites australis & Natural, experimental harvest in January & 33.4 & [57] \\
\hline 10 & Floodplain meadow & USA & $\begin{array}{l}\text { Carex aquatilis, } \\
\text { Carex utriculata }\end{array}$ & Natural, previous grazing, live + dead biomass & 43.1 & [52] \\
\hline 11 & Reedbed/swamp & Egypt & Phragmites australis & Natural, no management, polluted lake & 53.9 & [58] \\
\hline 12 & Coastal meadow & Estonia & $\begin{array}{l}\text { Elytrigia repens, } \\
\text { Festuca rubra etc. }\end{array}$ & Semi-natural, grazing & 3.1 & [11] \\
\hline 13 & Wet meadow & Germany & $\begin{array}{l}\text { Holcus lanatus, } \\
\text { Cynosurus cristatus, }\end{array}$ & Semi-natural, one (in July/August) or two cuts, no fertilisation & 4.1 & [51] \\
\hline 14 & Floodplain meadow & Estonia & $\begin{array}{l}\text { Phalaris arundinaceae, } \\
\text { Filipendula ulmaria etc. }\end{array}$ & Semi-natural, harvest in July, no fertilisation & 6.6 & {$[17,18,106]$} \\
\hline 15 & Floodplain meadow & Estonia & Carex acuta & Semi-natural, harvest in July, no fertilisation & 9.4 & [16] \\
\hline 16 & Floodplain meadow & Estonia & Filipendula ulmaria & Semi-natural, harvest in July, no fertilisation & 10.3 & {$[16]$} \\
\hline 17 & Extracted peatland & Estonia & Phalaris arundinaceae & Artificial, cultivated with fertilisation, harvest in October, & 7.2 & [64] \\
\hline 18 & Rewetted peatland & Italy & Phragmites australis & Artificial, restoration, revegetation, former drained agricultural land & 49.4 & {$[66]$} \\
\hline
\end{tabular}


climates up to more than $50 \mathrm{t} / \mathrm{ha}$ can be achieved [56-58], (Table 1). A similar trend can be observed in sedge-dominated floodplain meadows (e.g. [16,52]). In addition to temperature, the local water table and nutrient availability are important parameters in determining biomass production [59-61]. For example, the high yield of water-tolerant plant species growing in river-bank or delta areas typically leads to eutrophication and a consequent accumulation of nutrients.

\subsection{Biomass production of various wetland species and types}

The production of herbaceous biomass from wetland varies by wetland type and also by the dominant plant species (Table 1). Aboveground biomass production from 2.5 to $3.5 \mathrm{t} /$ ha was observed in alkaline mires dominated by small sedges [62]. In swamps, biomass production was found to vary from 5 to $40 \mathrm{t} / \mathrm{ha}$ depending on the dominant species (reed, bulrush or cattail) [7]. In general, the average herbaceous biomass production in wetlands was $12.3 \mathrm{t} /$ ha for cattail (Typha spp.), 17.6 t/ha for common reed (Phragmites spp.), 27.9 t/ha for giant cane (Arundo donax) and $43.0 \mathrm{t} / \mathrm{ha}$ for papyrus sedge (Cyperus papyrus) [63]. In Estonian climatic conditions, natural reedbeds dominated by the common reed produced almost $9.0 \mathrm{t} /$ ha [54], (Table 1). This yield was lower than that of Estonian natural floodplain meadows dominated by slender tufted-sedge (Carex acuta) or by meadowsweet (Filipendula ulmaria) (11.2 and 12.8 t/ha [16], respectively). The last two species communities are among the most productive in boreal floodplain meadows. The yield of these floodplain meadows was higher than that from Estonian extracted peatland cultivated with reed canary grass (8.2t/ha), even though that was the only area in our study that was supplied with additional fertilisers and harvested at the end of the growing season [64]. A similarly low yield of 6-7t/ha for this species has also been modelled for boreal zone soils with $\mathrm{N}>0.6 \%$ [65]. In extracted peatlands, the revegetation yield may be controlled by both the water table and by nutrient availability (e.g. [66]), and a more productive species or species communities well adapted to wetland conditions should be considered after restoration in order to increase the biomass yield.

\subsection{Management and problems with harvesting}

Wetland management regimes may be intensive (e.g., drained peatland for peat excavation, seasonally flooded meliorated polders, drained wet meadows for intensive agriculture, etc.), extensive (e.g., semi-natural coastal or salt marsh grasslands, alluvial/flooded wet meadows, sedge meadows managed extensively by mowing and/or grazing, etc.) or without management (e.g., natural swamps dominated by cattail or common reed, active Sphagnum acid bogs, etc.).

Mowing or grazing is a traditional and extensive anthropogenic intervention to keep wetlands open for biodiversity purposes
$[2,3,6,67]$. It has been assumed that grazing better supports the conservation value of various semi-natural wet grasslands than does mowing [68], but in some cases grazing has been reported to degrade fen wetlands beyond recovery [69]. Mowing, on the other hand, has been supposed to develop plant species' richness and to create wetland specialist habitats $[70,71]$. For specific habitat creation, it is sometimes important to organise, in addition to a periodic large-area harvest, a network of small meadow patches to preserve the characteristic plant species [72]. In order to conserve habitat-specific bird species in reedbeds and sedge-dominated meadows, reed cutting and mowing are obligatory, at least in a mosaic pattern $[46,73]$.

In the boreal zone, floodplain meadows typically reach maximum biomass production in July [18], but artificial peatland cultivated by reed canary grass reaches its maximum at the end of the growing season [64]. In practice, wet soil conditions may hamper access by heavy equipment while harvesting, so the management of wet meadows with traditional agri-technology requires extra effort and additional energy input [17,74-76]. In some cases, it is suggested to harvest the biomass of reed canary grass cultivated in extracted peatlands in the following spring in order to eliminate unwanted elements in the biomass and to benefit from the frozen ground (e.g., [77,78]), but this practice may result in a drastic loss of biomass [64,79]. Even a specially constructed harvester (e.g., a redesigned alpine snow-grooming machine) may negatively affect habitat-specific species and soil chemistry in sedgedominated wetlands [62]. Finding a proper harvesting technique is one of the most serious challenges in wetland management, and therefore a holistic approach based on both ecosystem-services provisions and specific harvesting techniques, logistics and infrastructure is required [80-82].

\section{Wetland herbaceous biomass characteristics}

\subsection{Chemical composition of biomass from various wetlands}

Many studies have demonstrated that the composition of herbaceous biomass depends upon its origin [83-85]. The main challenge in converting herbaceous biomass to bioenergy is the great variability of its chemical composition [17,86-88]. For instance, lignocellulosic compounds do not easily biodegrade under anaerobic conditions, and therefore a low biogas yield can be expected [89,90]. A high concentration of lignin in biomass (the critical level is $100 \mathrm{~g}$ lignin per $\mathrm{kg}$ volatile solids) is considered to inhibit its methane potential [89]. Therefore, a large content of easily biodegradable compounds in biomass (e.g., proteins, hemicellulose) is favoured for methane production via anaerobic digestion. It has been shown that the feedstock-specific methane yield of herbaceous biomass correlates to its protein content [91], but, on the other hand, extremely large amounts of protein or $\mathrm{N}$ in feedstock may form ammonium, thus inhibiting methane production

Table 2

Composition of biomass (\%DM) in different wetlands (numbering and references according to Table 1) and functional groups (G - grasses (Poaceae); S\&R - sedges (Cyperaceae) and rushes (Juncaceae); L - legumes (Fabaceae); OF - other dicotyledonous broad-leaved forbs (data modified from [17,18,86,106]).

\begin{tabular}{|c|c|c|c|c|c|c|c|c|c|c|c|c|c|c|c|}
\hline Parameters & 1 & 2 & 3 & 5 & 6 & 12 & 13 & 14 & 15 & 16 & 17 & G & S\&R & $\mathrm{L}$ & $\mathrm{OF}$ \\
\hline Cellulose & & & & & & & & 29.5 & & & & 32.2 & 29.7 & 23.9 & 23.9 \\
\hline Hemicellulose & & & & & & & & 22.8 & & & & 24.7 & 30.8 & 12.1 & 7.4 \\
\hline Lignin & & & & & & & & 8.9 & & & & 6.1 & 5.6 & 10.2 & 11.3 \\
\hline Crude protein & 9.4 & 8.1 & 6.3 & 10.0 & 11.9 & 10.6 & 8.1 & 9.5 & 9.4 & 10.0 & 6.0 & 8.4 & 9.5 & 17.1 & 10.5 \\
\hline Ash & & 7.9 & & & & & 7.2 & 6.2 & & & & 7.0 & 5.4 & 5.9 & 6.5 \\
\hline $\mathrm{C}$ & 42.3 & & 46.5 & & & 42.5 & & 44.7 & & & 47.4 & 44.0 & 44.8 & 45.8 & 45.1 \\
\hline $\mathrm{N}$ & 1.5 & 1.3 & 1.0 & 1.6 & 1.9 & 1.7 & 1.3 & 1.5 & 1.5 & 1.6 & 0.96 & 1.3 & 1.5 & 2.7 & 1.7 \\
\hline$P$ & 0.05 & & & 0.20 & 0.25 & 0.05 & & 0.16 & 0.20 & 0.24 & & 0.14 & 0.12 & 0.16 & 0.17 \\
\hline $\mathrm{K}$ & 1.53 & 1.59 & 1.0 & 1.01 & 1.31 & 1.55 & 0.81 & 1.5 & 1.09 & 1.25 & & 1.05 & 1.07 & 0.89 & 1.40 \\
\hline $\mathrm{Ca}$ & 0.25 & 0.76 & & 0.61 & 1.24 & 0.30 & 0.99 & 0.77 & 0.65 & 1.09 & & 0.32 & 0.60 & 1.33 & 1.14 \\
\hline $\mathrm{Mg}$ & 0.36 & 0.26 & & 0.24 & 0.35 & 0.46 & 0.45 & 0.19 & 0.27 & 0.32 & & 0.14 & 0.17 & 0.34 & 0.42 \\
\hline $\mathrm{Cl}$ & & 0.74 & 0.40 & & & & 0.22 & 0.14 & & & 0.19 & 0.18 & 0.13 & 0.15 & 0.12 \\
\hline$S$ & & 0.25 & 0.20 & & & & 0.27 & 0.18 & & & 0.17 & 0.21 & 0.22 & 0.18 & 0.18 \\
\hline
\end{tabular}




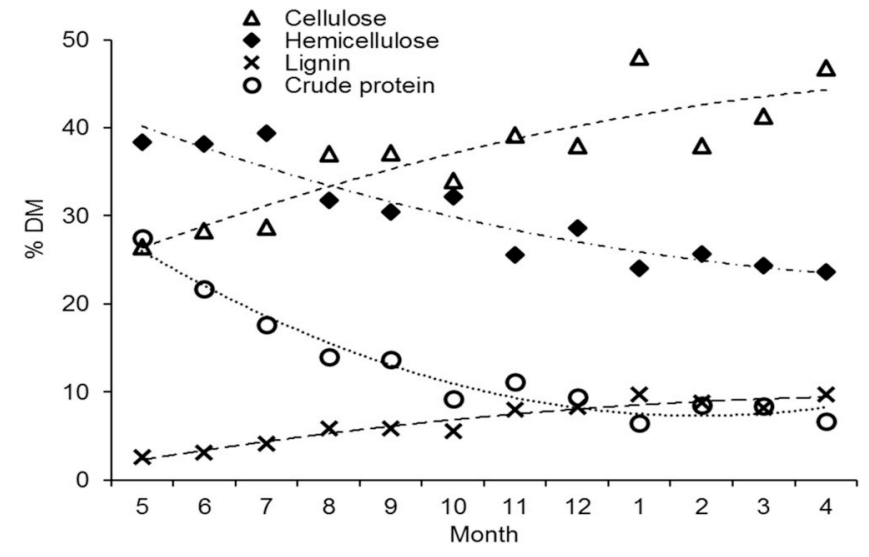

Fig. 1. Dynamics of biomass composition in common reed (Phragmites australis) collected from floodplain meadow from May 2016 to April 2017.

[92]. In general, the cellulose and hemicellulose content in grasses, sedges and rushes is greater than that in legumes and other forbs, while for lignin and protein content the situation is reversed (Table 2). A similar trend has been observed in other studies [83]. High grass or sedges/rushes content in feedstock has been found to produce a higher sugar content, which is more easily digestible than forbs-rich feedstock, resulting in higher saccharification yields [93]. This assumption was also confirmed for the South American wetland sedge (Schoenoplectus californicus, spp. Totora), which was presumed to be a promising cosubstrate for biogas production [94]. In another study, however, a high ratio of sedges and rushes in biomass was deemed less suitable for biogas production than the biomass from other grasslands [88]. Therefore, the suggestion of any particular functional group as a methane production substrate solely on the basis of its chemical composition is complicated, as the dicotyledonous plant species with a high protein concentration also have higher lignin amounts. The effectiveness of wetland biomass for methane potential is analysed in section 4.2 .

If direct combustion is chosen as the energy conversion method, other criteria for substrate quality become important. As a rule, a higher heating value is considered to correlate with a higher $\mathrm{C}$ concentration [95], as each extra $1 \%$ of mineral ash is assumed to decrease the heating value by $0.2 \mathrm{MJ} / \mathrm{kg}$ [96]. Our comparison revealed a high C concentration in the biomass of common reed reedbeds and in reed canary grass from late harvest monoculture (Table 2). Relatively higher ash concentrations ( $>7 \% \mathrm{DM}$ ) have been measured in biomasses harvested from wet meadows or tall-sedge swamps. In another study from a floodplain meadow, a somewhat lower ash content in sedges and rushes was detected $(5.4 \% \mathrm{DM})$. Therefore, it can be assumed that the ash content of a functional group may vary according to particular kinds of wetland-management regime. Increased ash and alkali metal content can both result in slagging, corrosion and fouling of a boiler that is not dedicated to herbaceous biomass burning [97]. In our database, the highest $\mathrm{K}$ and $\mathrm{Mg}$ concentrations among functional groups were achieved from the group of other forbs. This functional group is probably more common in coastal meadows and floodplain meadows than in reedbeds or wet meadows, causing slight differences in element concentrations by wetland type. The highest Ca concentration among the functional groups was found in legumes, but the small ratio of this group in various wetlands probably veiled its impact, and the greatest concentration of Ca was detected in floodplain meadows dominated by meadowsweet. $\mathrm{P}$ concentration in all our investigated functional groups was lower than that in most wetland types. This phenomenon can be explained by local differences in alluvial sediments; $\mathrm{P}$ is a common element in waterbodies under eutrophication, and therefore its uptake potential and concentration reflect pollution in the local environment [98-100]. In general, dicotyledonous species had higher concentrations of alkali metals than monocotyledonous species, and this ratio should be controlled when designing suitable combustion technology for wetland biomass.

One crucial factor in direct combustion is the chemical composition of emission gases. To diminish problems with $\mathrm{NO}_{\mathrm{x}}$ and $\mathrm{SO}_{\mathrm{x}}$ emissions, $\mathrm{N}$ and $\mathrm{S}$ concentrations should be less than $6 \mathrm{~g} / \mathrm{kg}$-DM and $2 \mathrm{~g} / \mathrm{kg}$-DM, respectively [101]. The corrosion of the combustion system by the gases can be prevented if the raw material contains less than $1 \mathrm{~g} \mathrm{~S}$ and $\mathrm{Cl}$ per $\mathrm{kg}$-DM. The critical level for $\mathrm{N}$ was exceeded in all the biomasses in our database, and that for $\mathrm{S}$ and $\mathrm{Cl}$ in tall sedge swamps, wet meadows and reedbeds (see Table 2). Again, it is necessary to point out the impact of the study site, as $S$ availability may vary due to the characteristics of the growth substrate (e.g. [102]). Conversely to alkaline metals, $\mathrm{Cl}$ and S concentrations are higher in monocotyledonous than in dicotyledonous species, and that pattern should be kept in mind when changing the raw material for a herbaceous biomass boiler to avoid an additional risk of environmental pollution.

\subsection{Changes in chemical composition during the vegetation period}

Changes in the composition of herbaceous biomass have been reported by various studies $[18,51,64,83]$. In our study, the seasonal dynamics of organic compounds were demonstrated on the basis of biomass from the common reed collected in a floodplain meadow (composition of biomass was analysed according to [103]); the cellulose and lignin concentrations increased, and the hemicellulose and crude protein concentrations decreased in the course of biomass aging (Fig. 1). At the beginning of the vegetation period, both protein and cellulose concentrations were about $30 \%$, and the hemicellulose and lignin concentrations were about $40 \%$ and $3 \%$, respectively. At the end of vegetation period (October), both the protein and hemicellulose concentrations had decreased (to $9.0 \%$ and $30 \%$, respectively), while those of cellulose and lignin increased (to $35 \%$ and $6 \%$, respectively). During the dormancy period, an additional decline in protein content and an increase in cell wall components was observed. A similar trend during the vegetation period has been reported through grass maturity stages [104].

Harvesting herbaceous biomass at the end of the vegetation period should be considered $[18,51]$ to decrease the content of the minerals crucial in combustion that are mentioned in section 3.1. In the current study about biomass of common reed (chemical characteristics of biomass were analysed based on [103]), the most drastic declines during the vegetation period were observed for $\mathrm{K}$ and $\mathrm{P}$ (from $4 \%$ to $\approx 1 \%$ and from $0.55 \%$ to $0.15 \%$, respectively) (Fig. 1). Similar negative trends were detected for $\mathrm{Ca}$ and $\mathrm{Mg}$. All these elements also continued to decrease in the biomass throughout the dormancy period. In reed canary grass, a decrease in $\mathrm{N}, \mathrm{Cl}$ and $\mathrm{S}$ during biomass aging has been reported, followed by an ash content decrease and a $\mathrm{C}$ ratio increase [64].

The calorific value of common reed biomass ranged from about $17.0 \mathrm{MJ} / \mathrm{kg}$ to more than $18.0 \mathrm{MJ} / \mathrm{kg}$ (calorific value based on ovendried biomass combusted in bomb calorimeter (e2K, Digital Data Systems (Pty) Ltd, South Africa)), with a tendency to increase during biomass aging (Fig. 2). The same pattern of calorific value growth (from $16.7 \mathrm{MJ} / \mathrm{kg}$ in summer to $17.2 \mathrm{MJ} / \mathrm{kg}$ the following spring) was also detected in reed canary grass biomass [64]. Typical calorific values for perennial energy grasses (Phalaris arundinacea, Panicum virgatum and Miscanthus spp.) varied from 16.6 to $17.6 \mathrm{MJ} / \mathrm{kg}$, respectively [78].

\section{Sustainability for bioenergy purposes}

\subsection{Wetland energy potential}

Traditionally, biomass from wetlands has been used for diverse purposes including food, construction material and fodder $[6,105]$. Recently, herbaceous biomass has drawn more attention because of its 


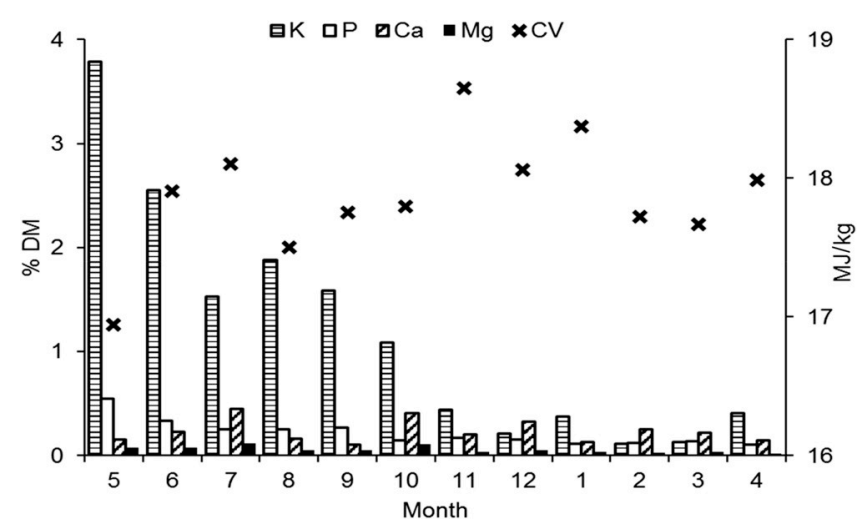

Fig. 2. Dynamics of chemical elements and experimental calorific value in biomass of common reed (Phragmites australis) collected from floodplain meadow from May 2016 to April 2017. Column with horizontal stripes represent potassium, white column phosphorus, column with diagonal stripes calcium and black column magnesium; black cross represents calorific value.

bioenergy potential $[86,87,106-111]$. The energy potential per area depends mainly on biomass production [87,106,108,109,112,113].

Judging by the dry biomass production (Table 1 ) and calorific values $(18.6 \mathrm{MJ} / \mathrm{kg}$ [54] for 1,3 and 12; $18.4 \mathrm{MJ} / \mathrm{kg}$ [106] for 5, 6 and 14-16; $16.9 \mathrm{MJ} / \mathrm{kg}$ [64] for 17), the highest energy potential can be achieved from natural wetlands (Fig. 3): floodplain meadows dominated by meadowsweet or tall sedge (Carex acuta) (236 GJ/ha and $206 \mathrm{GJ} /$ ha, respectively), followed by reedbeds and coastal meadows dominated by the common reed $(160 \mathrm{GJ} / \mathrm{ha}$ and $121 \mathrm{GJ} / \mathrm{ha}$, respectively). Wetland management decreases its energy potential. The highest energy potential among seminatural wetlands can be obtained from floodplain meadows dominated by meadowsweet or tall sedge (190 GJ/ha and $173 \mathrm{GJ} / \mathrm{ha}$, respectively). Boreal floodplain meadows had an average energy potential of around $122 \mathrm{GJ} / \mathrm{ha}$. This value is similar to the energy potential of reed canary grass cultivated in extracted peatlands. According to the literature, the energy potential of the studied wetlands is comparable to the energy yield from various biomass sources (wheat, switchgrass, Miscanthus sp., poplar and willow) [114]. Therefore, these can be good bioenergy sources without additional fertiliser input or a change in land use that diminishes biodiversity. Assuming the energy-conversion efficiency via combustion (to produce heat) to be only 85\% [115], we would obtain 104-162 GJ/ ha from floodplain meadows, $136 \mathrm{GJ} /$ ha from reedbeds and $104 \mathrm{GJ} / \mathrm{ha}$ from cultivated extracted peatlands. Usually, the energy input for harvesting in paddy fields is assumed to be about $1 \mathrm{GJ}$ ha-1 [116], but according to other authors, grassland management requires a total energy input in the range of 4-10 GJ/ha [117-119]. Even in the case of the highest assumed energy input of $10 \mathrm{GJ} / \mathrm{ha}$ for management, we could obtain from 94 to $152 \mathrm{GJ} /$ ha of net heat energy from floodplain meadows, $126 \mathrm{GJ} /$ ha from reedbeds and $94 \mathrm{GJ} /$ ha from cultivated extracted peatlands in the boreal zone.

\subsection{Wetland biomass conversion to biofuel}

In the current study, the average cumulative methane yield of herbaceous biomass varied across functional groups and over time (Fig. 4). In the first week, higher methane yields were observed in legumes and other forbs groups. Such rapid progress was most likely supported by higher $\mathrm{N}$ and $\mathrm{P}$ content in the legumes and other forbs. The mineralisation process of both these elements may promote the microbial biomass growth and acetate metabolism that accelerate methane production $[86,120,121]$. At the end of the experiment, the methane potential was higher in sedges and rushes $\left(0.40 \mathrm{~m}^{3} \mathrm{CH}_{4} / \mathrm{kg}-\mathrm{VS}\right)$, followed by grasses $\left(0.32 \mathrm{~m}^{3} \mathrm{CH}_{4} / \mathrm{kg}\right.$-VS $)$, legumes $\left(0.30 \mathrm{~m}^{3} \mathrm{CH}_{4} / \mathrm{kg}\right.$ VS) and other forbs $\left(0.24 \mathrm{~m}^{3} \mathrm{CH}_{4} / \mathrm{kg}\right.$-VS). For total biomass collected from floodplain meadow, the methane potential was $0.27 \mathrm{~m}^{3} \mathrm{CH}_{4} / \mathrm{kg}$ VS. The higher methane potential from grasses and sedges/rushes than from legumes and other forbs is confirmed by the results of other studies [122,123] The methane potential of various functional groups was in the same range as the methane potential of some grass species (Poa pratensis, Poa abbreviata, Phalaris arundinacea, Phragmites australis) and other forbs (Aegopodium podagraria, Helianthus salicifolius, Matricaria chamomilla, Taraxacum spp.) or energy crops that were harvested in summer [89,123-125]. It was observed that the biogas potential of Phragmites australis depends on the time of harvest [126]. Generally, differences in methane potential are explained by a feedstock's chemical composition and by its varying indigestible fraction of organic fibres or degree of cellulose crystallinity [89,127]. Quite often, selected pre-treatment techniques that remove the indigestible fraction from the biomass may enhance the digestibility of the biogas substrate and thus increase methane production [123,128].

According to our calculations, $122 \mathrm{GJ} /$ ha can potentially be achieved from floodplain meadows in terms of heat (see section 4.1). If we consider the same biomass production (No 14 in Table 1), achieved methane potential (total biomass in Fig. 4) and assume a $\mathrm{CH}_{4}$ calorific value of $39.7 \mathrm{MJ} / \mathrm{m}^{3}$, we can produce only $65 \mathrm{GJ} / \mathrm{ha}$, which is almost $50 \%$ less through heat production via direct combustion (Fig. 5). For hemp, the ratio between biomass energy yield and methane-produced energy yield has been reported as $47 \%$ [129]. According to another study, only $25-30 \%$ of energy can be converted to methane in the biomass from various semi-natural areas in Belgium [130]. For the area-specific ethanol energy yield of the same biomass (14 in Table 1), we used the experimental ethanol production ratio of $115.7 \mathrm{~g} / \mathrm{kg}-\mathrm{DM}$ [131] and the calorific value of ethanol of $29.7 \mathrm{MJ} / \mathrm{kg}$. Based on these assumptions, the floodplain energy yield in terms of ethanol was $23 \mathrm{GJ} /$ ha, or about $20 \%$ of that from direct combustion. A much lower energy yield via ethanol production compared to methane production was also achieved from Zea mays and Vicia faba cultivated in the boreal zone [132]. One possible solution for increasing the efficiency of both biogas and ethanol production is pre-treatment of the substrates [128,133]. Without a proper pre-treatment that efficiently destroys (hydrolyses) the cellulose of a herbaceous substrate [134,135], ethanol production from wetland biomass cannot be suggested. On the other hand, its chemical composition may be more profitable for other biorefinery options.

\subsection{Biorefinery}

The concept of a biorefinery integrates processes and technologies for the resource-efficient use of all lignocellulosic biomass components in order to convert such material into high-value-added products

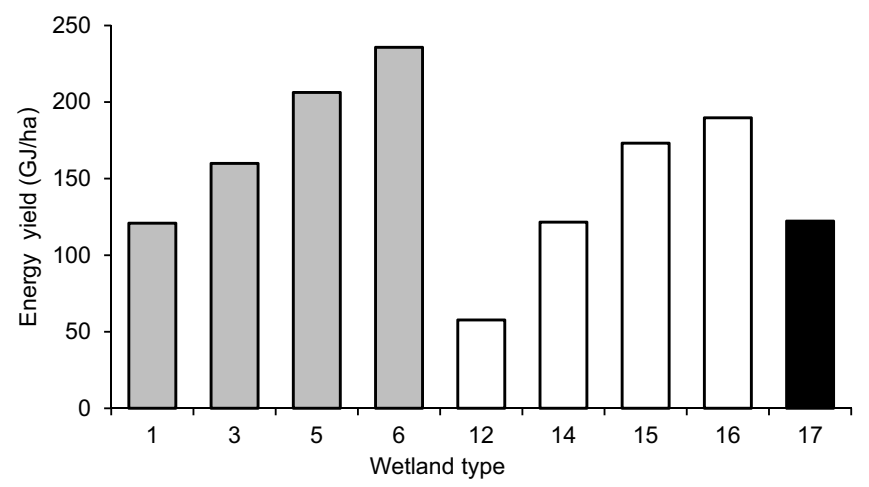

Fig. 3. Energy potential in different boreal wetlands (numbering according to Table 1) according to disturbance level (gray column - natural; white column semi-natural; black column - artificial). Energy potential based on calculation of dry biomass yield and calorific value (18.6 MJ/kg [54] for 1, 3 and 12; $18.4 \mathrm{MJ} / \mathrm{kg}$ [106] for 5, 6 and14-16; 16.9 MJ/kg [64] for 17). 


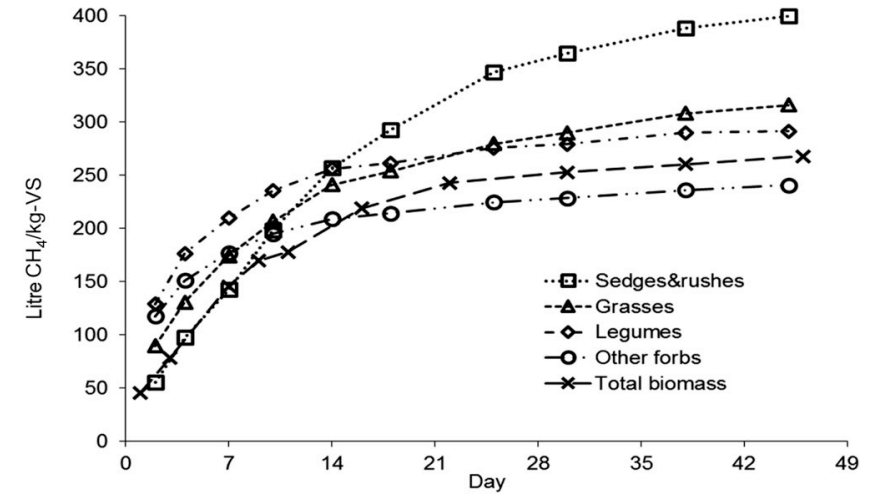

Fig. 4. Methane yield by different functional groups and total mix biomass from floodplain meadows (data modified from [86,107]).

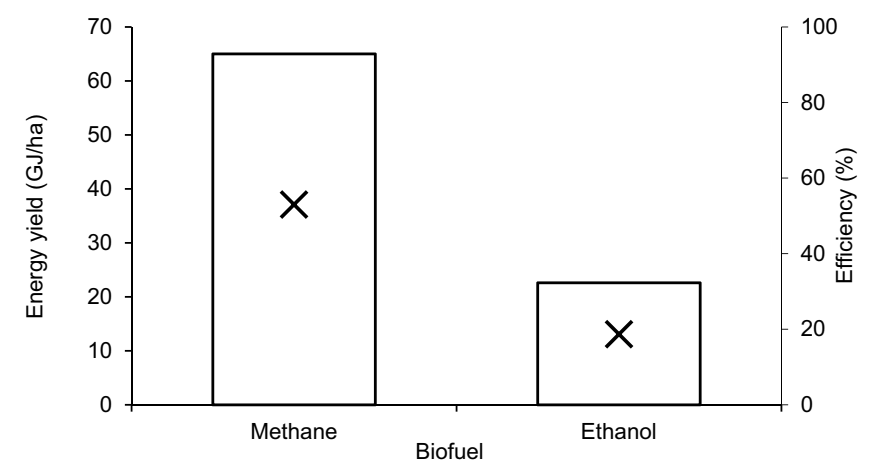

Fig. 5. Biofuels energy yield (column) and conversion efficiency (cross) in biomass from floodplain meadows. The methane and ethanol yield in total biomass based on Fig. 4 and $115.7 \mathrm{~g} \mathrm{~kg}^{-1} \mathrm{DM}$ [110], respectively. $\mathrm{CH}_{4}$ and $\mathrm{C}_{2} \mathrm{H}_{5} \mathrm{OH}$ calorific value were assumed to be $39.7 \mathrm{MJ} / \mathrm{m}^{3}$ and $29.7 \mathrm{MJ} / \mathrm{kg}$, respectively. Conversion efficiency based on ratio of biofuel and potential energy.

[133,136-138]. Biorefining is driven by global environmental challenges and the demands of a future bioeconomy [139-141]. The sustainable production of energy, fuels, organic chemicals and polymers from biomass in an integrated biorefinery approach is required to decrease dependence on fossil resources and address energy and material crises [142-145]. The development of biorefinery systems could promote the efficiency of wetland biomass use and protect the environment (e.g. [87,109,146,147]). Within the arena of biorefinery, bioenergy (bioheat and biopower, gaseous and liquid biofuels) is most probably a high-volume, low-value product, but the conceptual vision of biorefinery embraces much more ambitious plans for diverse bioproducts [139]. One approach involves the depolymerisation of lignocellulosic material to produce eco-friendly biodegradable PHAs that can replace fossil-fuel-based plastic (e.g. [148,149]). Wetland biomass could also replace forest harvesting for paper production [150]. Some wetland plant species have also drawn attention for medicinal production (e.g. Filipendula ulmaria or Carex spp. in [151-154]).

\subsection{Socioeconomic impact}

The rapid growth and high density of the root systems of typical wetland species have inspired engineers to design specially constructed wetland systems [155]. Such tailor-made constructions may have a broad variety of functions; for example, they could be used to treat the effluent of municipal sewage, to filter runoff from a collection of captive wildfowl, to neutralise the acidic drainage water from mines, to buffer sensitive areas downstream from intensively managed agricultural fields and to protect a drinking water reservoir from the impact of traffic (e.g., [156-158]). According to the constructed wetland's function, the water would flow on the wetland surface or subsurface [155]. In both cases, the water-tolerant wetland plant species promote treatment processes via direct element uptake and metabolism. Moreover, the roots of these plants mediate oxygen transfer to the rhizosphere and therefore increase the aerobic degradation of organic materials together with an expected nitrification [159]. It has been shown that the concentration of trace metals in the common reed and reed canary grass growing in constructed wetlands did not exceed that in the same species in natural wetlands [157]. Therefore, the biomass from constructed wetlands may also be counted as a potential raw material for bio-based products. Moreover, more intense exploitation of the biomass originating from small-scale, alternative, eco-friendly purification facilities promotes the idea of sustainable development and improves quality of life, supporting the promise of an agroecological lifestyle [63,108].

Another reason to increase wetland area is to restore previously managed peatland areas. Without a good management plan, the top layer in these areas experiences continuous mineralisation due to the decreased water table. The consequent greenhouse gas emission should be avoided through the wet cultivation in peatlands of previously selected potential crops $[85,160,161]$. Such paludiculture systems, if planted with natural, high-yielding plant species under a reasonable and efficient management plan, would constitute an additional agroecological approach to meet both nature-conservation and bio-economy goals.

\subsection{Ecological impact}

The importance of wetland restoration is also manifested in largescale natural-habitat conservation programs organised at the local-authority level in response to the demands of local residents [162]. Cypress swamps and wetlands in Palm Beach County, Florida, provide local habitats with protected surface water, ensure groundwater quality and quantity, create conservation greenways and wildlife corridors and provide opportunities for recreation through hiking and bird watching. Through careful planning, these goals can be achieved in cooperation with habitat conservation. Due to seasonal intensive flooding and lack of terrestrial access, floodplain meadows may serve as an excellent refuge for migrating birds and may decrease their damage in farmers' fields [163]. Moreover, being less disturbed than conventional agricultural areas, they promote the nesting of farmland birds, whose nesting period should be considered in wetland biomass harvest plans $[164,165]$. It has been shown that some bird species are sensitive to changes in the flooding regime [166]. At the same time, it may be necessary to maintain a high-water table in wetlands for some endemic plant species (e.g., Senecio fontanicola [167]), and large-scale drainage can degrade the habitat for characteristic species (e.g., Carex spp. [168]). Continuing habitat fragmentation or destruction may lead to the extinction of wetland specialists (e.g., Swertia perennis [169]). Therefore, a careful inventory of local biodiversity through the seasons should be undertaken before making drastic changes in wetland management plans. A careful approach based on broad-scale background information guarantees an optimal design that serves sustainable development goals.

\section{Conclusions}

- Biomass production in natural and semi-natural floodplain meadows is higher than in cultivated extracted peatlands in the boreal zone.

- Sedges (Carex spp.), meadowsweet (Filipendula ulmaria) or the common reed (Phragmites australis) should be favoured in wetlands if a high biomass yield is required.

- Summer biomass from wetlands contains minerals unwanted for combustion, but a reasoned choice of harvest time decreases the concentration of these crucial elements.

- The high hemicellulose and low lignin content of sedges and rushes 
and their larger proportion in total biomass may enhance methane production.

- The highest theoretical energy potential was achieved from floodplain meadows, followed by reedbeds. Based on various conversion options, we conclude that ca. $50 \%$ of theoretical potential was captured in methane, while the ethanol production efficiency was $20 \%$.

- Improved knowledge of wetlands biomass production with sustainable management options is needed to promote the development of other bio-based products to diversify and enhance local bioeconomy.

\section{Acknowledgements}

The authors thank Epp Libe for fieldwork of common reed biomass sampling and Mai Olesk for the laboratory analyses in the Laboratory of Plant Biochemistry of the Estonian University of Life Sciences. We thank Eike Eller for providing general remarks and anonymous editor for language correction. We acknowledge Editor-in-Chief Dr. Aoife M. Foley and anonymous reviewers for their useful comments. This work was supported by the Japan Society for the Promotion of Science [grant number 16F16755]; the Estonian Research Council [grant numbers PUT 1463, MOBTB122].

\section{References}

[1] Ramsar Convention Secretariat. An introduction to the convention on wetlands. 5th ed. Gland: Ramsar Convention Secretariat; 2016.

[2] Westlake DF, Květ J, Szczepański A, editors. The production ecology of wetlands: the IBP synthesis Cambridge: Cambridge University Press; 1999. https://doi.org/ 10.1017/СBO9780511549687.

[3] Keddy PA. Wetland ecology: principles and conservation. 2nd ed. Cambridge: Cambridge University Press; 2010. https://doi.org/10.1017/CBO9780511778179.

[4] Dahl TE. Status and trends of wetlands in the conterminous United States 2004 to 2009. Washington, DC. 2011.

[5] Rydin H, Jeglum J. The biology of peatlands. 2nd ed. Oxford: Oxford University Press; 2013.

[6] Mitsch WJ, Gosselink JG. Wetlands. 5th ed. Hoboken: John Wiley \& Sons; 2015.

[7] Leuschner C, Ellenberg H. Ecology of central european non-forest vegetation: coastal to alpine, natural to man-made habitats. Cham: Springer International Publishing; 2017. https://doi.org/10.1007/978-3-319-43048-5.

[8] Valkama E, Lyytinen S, Koricheva J. The impact of reed management on wildlife: a meta-analytical review of European studies. Biol Conserv 2008;141:364-74https://doi.org/10.1016/j.biocon.2007.11.006.

[9] Srivastava J, Kalra SJS, Naraian R. Environmental perspectives of Phragmites australis (cav.). Trin. Ex. Steudel. Appl Water Sci 2014;4:193-202. https://doi.org/ 10.1007/s13201-013-0142-x.

[10] Packer JG, Meyerson LA, Skálová H, Pyšek P, Kueffer C. Biological flora of the British isles: Phragmites australis. J Ecol 2017;105:1123-62. https://doi.org/10. 1111/1365-2745.12797.

[11] Sammul M, Kauer K, Köster T. Biomass accumulation during reed encroachment reduces efficiency of restoration of Baltic coastal grasslands. Appl Veg Sci 2012;15:219-30. https://doi.org/10.1111/j.1654-109X.2011.01167.x.

[12] Cronk JK, Fennessy MS. Wetland plants. In: Likens GE, editor. Encycl. Inl. Waters. Oxford: Academic Press; 2009. p. 590-8https://doi.org/10.1016/B978012370626-3.00060-0.

[13] Kuehn KA, Ohsowski BM, Francoeur SN, Neelyb RK. Contributions of fungi to carbon flow and nutrient cycling from standing dead Typha angustifolia leaf litter in a temperate freshwater marsh. Limnol Oceanogr 2011;56:529-39. https://doi. org/10.4319/1o.2011.56.2.0529.

[14] Deák B, Valkó O, Török P, Kelemen A, Tóth K, Miglécz T, et al. Reed cut, habitat diversity and productivity in wetlands. Ecol Complex 2015;22:121-5https://doi. org/10.1016/j.ecocom.2015.02.010.

[15] Rogers SMD. Tissue culture and wetland establishment of the freshwater monocots Carex, Juncus, Scirpus, and Typha. Vitro Cell Dev Biol Plant 2003;39:1-5. https:// doi.org/10.1079/IVP2002358.

[16] Neuenkamp L, Metsoja JA, Zobel M, Hölzel N. Impact of management on biodiversity-biomass relations in Estonian flooded meadows. Plant Ecol 2013;214:845-56. https://doi.org/10.1007/s11258-013-0213-y.

[17] Melts I, Heinsoo K, Ivask M. Herbage production and chemical characteristics for bioenergy production by plant functional groups from semi-natural grasslands. Biomass Bioenergy 2014;67:160-6. https://doi.org/10.1016/j.biombioe.2014.04 037.

[18] Melts I, Heinsoo K. Seasonal dynamics of bioenergy characteristics in grassland functional groups. Grass Forage Sci 2015;70:571-81. https://doi.org/10.1111/gfs. 12155 .

[19] Metsoja J-A, Neuenkamp L, Pihu S, Vellak K, Kalwij JM, Zobel M. Restoration of flooded meadows in Estonia - vegetation changes and management indicators.
Appl Veg Sci 2012;15:231-44. https://doi.org/10.1111/j.1654-109X.2011. 01171.x.

[20] Lavergne S, Molofsky J. Reed canary grass (Phalaris arundinacea) as a biological model in the study of plant invasions. CRC Crit Rev Plant Sci 2004;23:415-29. https://doi.org/10.1080/07352680490505934.

[21] Weilhoefer CL, Williams D, Nguyen I, Jakstis K, Fischer C. The effects of reed canary grass (Phalaris arundinacea L.) on wetland habitat and arthropod community composition in an urban freshwater wetland. Wetl Ecol Manag 2017;25:159-75. https://doi.org/10.1007/s11273-016-9507-x.

[22] European Commission. Interpretation manual of European Union habitats EUR28. European Commision DG-ENV; 2013.

[23] Ramsar Convention on Wetlands. Global wetland outlook: state of the world's wetlands and their services to people. Gland. 2018.

[24] Clarkson BR, Ausseil A-GE, Gerbeaux P. Wetland ecosystem services. In: Dymond JR, editor. Ecosyst. Serv. New zeal. - cond. Trends. Lincoln: Manaaki Whenua Press, Landcare Research; 2013. p. 192-202.

[25] Mitsch WJ, Bernal B, Hernandez ME. Ecosystem services of wetlands. Int J Biodivers Sci Ecosyst Serv Manag 2015;11:1-4. https://doi.org/10.1080/ 21513732.2015.1006250.

[26] Kiviat E. Ecosystem services of Phragmites in North America with emphasis on habitat functions. AoB Plants 2013;5:plt008. https://doi.org/10.1093/aobpla/ plt008.

[27] Irvine K. Editorial: aquatic conservation in the age of the sustainable development goals. Aquat Conserv Mar Freshw Ecosyst 2018;28:1264-70. https://doi.org/10. 1002/aqc.3007.

[28] Villa JA, Bernal B. Carbon sequestration in wetlands, from science to practice: an overview of the biogeochemical process, measurement methods, and policy framework. Ecol Eng 2018;114:115-28https://doi.org/10.1016/j.ecoleng.2017.06. 037.

[29] Tockner K, Stanford JA. Riverine flood plains: present state and future trends. Environ Conserv 2002;29:308-30. https://doi.org/10.1017/ S037689290200022X.

[30] Sammul M, Kull T, Lanno K, Otsus M, Mägi M, Kana S. Habitat preferences and distribution characteristics are indicative of species long-term persistence in the Estonian flora. Biodivers Conserv 2008. https://doi.org/10.1007/s10531-0089393-5.

[31] Kimmel K, Kull A, Salm J-O, Mander Ü. The status, conservation and sustainable use of Estonian wetlands. Wetl Ecol Manag 2010;18:375-95. https://doi.org/10. 1007/s11273-008-9129-z.

[32] Krause B, Culmsee H, Wesche K, Bergmeier E, Leuschner C. Habitat loss of floodplain meadows in north Germany since the 1950s. Biodivers Conserv 2011;20:2347-64. https://doi.org/10.1007/s10531-011-9988-0.

[33] Davidson NC. How much wetland has the world lost? Long-term and recent trends in global wetland area. Mar Freshw Res 2014;65:934-41.

[34] Dixon MJR, Loh J, Davidson NC, Beltrame C, Freeman R, Walpole M. Tracking global change in ecosystem area: the Wetland Extent Trends index. Biol Conserv 2016;193:27-35https://doi.org/10.1016/j.biocon.2015.10.023.

[35] Hu S, Niu Z, Chen Y, Li L, Zhang H. Global wetlands: potential distribution, wetland loss, and status. Sci Total Environ 2017;586:319-27https://doi.org/10.1016/ j.scitotenv.2017.02.001.

[36] Ferreira M, Beja P. Mediterranean amphibians and the loss of temporary ponds: are there alternative breeding habitats? Biol Conserv 2013;165:179-86https://doi. org/10.1016/j.biocon.2013.05.029.

[37] Rannap R, Kaart T, Pehlak H, Kana S, Soomets E, Lanno K. Coastal meadow management for threatened waders has a strong supporting impact on meadow plants and amphibians. J Nat Conserv 2017;35:77-91https://doi.org/10.1016/j. jnc.2016.12.004.

[38] Drayer AN, Richter SC. Physical wetland characteristics influence amphibian community composition differently in constructed wetlands and natural wetlands. Ecol Eng 2016;93:166-74https://doi.org/10.1016/j.ecoleng.2016.05.028.

[39] Żmihorski M, Krupiński D, Kotowska D, Knape J, Pärt T, Obłoza P, et al. Habitat characteristics associated with occupancy of declining waders in Polish wet grasslands. Agric Ecosyst Environ 2018;251:236-43https://doi.org/10.1016/j. agee.2017.09.033.

[40] Melts I, Lanno K, Sammul M, Uchida K, Heinsoo K, Kull T, et al. Fertilising seminatural grasslands may cause long-term negative effects on both biodiversity and ecosystem stability. J Appl Ecol 2018;55. https://doi.org/10.1111/1365-2664. 13129. 1951-5.

[41] Cardinale BJ, Duffy JE, Gonzalez A, Hooper DU, Perrings C, Venail P, et al Biodiversity loss and its impact on humanity. Nature 2012;486:59-67. https://doi. org/10.1038/nature11148.

[42] Immoor A, Zacharias D, Müller J, Diekmann M. A re-visitation study (1948-2015) of wet grassland vegetation in the Stedinger Land near Bremen, North-western Germany. Tuexenia 2017;37:271-88. https://doi.org/10.14471/2017.37.013.

[43] Diekmann M, Andres C, Becker T, Bennie J, Blüml V, Bullock JM, et al. Patterns of long-term vegetation change vary between different types of semi-natural grasslands in Western and Central Europe. J Veg Sci 2019;30:187-202. https://doi.org/ 10.1111/jvs.12727.

[44] Joosten H, Clarke D. Wise use of mires and peatlands. Devon: international mire conservation group and international peat society. 2002.

[45] Max Finlayson C. Forty years of wetland conservation and wise use. Aquat Conserv Mar Freshw Ecosyst 2012;22:139-43. https://doi.org/10.1002/aqc.2233.

[46] Trnka A, Peterková V, Prokop P, Batáry P. Management of reedbeds: mosaic reed cutting does not affect prey abundance and nest predation rate of reed passerine birds. Wetl Ecol Manag 2014;22:227-34. https://doi.org/10.1007/s11273-0139325-3. 
[47] Heneberg P, Bogusch P, Tauchmanová P, Řezáč M, Astapenková A. Common reed (Phragmites australis) gall as the limiting nesting resource of rare wetland bees and wasps (Hymenoptera: aculeata \& Evanioidea) in Central Europe. Ecol Eng 2017;108:100-13https://doi.org/10.1016/j.ecoleng.2017.08.014.

[48] Pärn J, Verhoeven JTA, Butterbach-Bahl K, Dise NB, Ullah S, Aasa A, et al. Nitrogen-rich organic soils under warm well-drained conditions are global nitrous oxide emission hotspots. Nat Commun 2018;9. https://doi.org/10.1038/s41467018-03540-1.

[49] Davidson NC, Van Dam AA, Finlayson CM, McInnes RJ. Worth of wetlands: revised global monetary values of coastal and inland wetland ecosystem services. Mar Freshw Res 2019. https://doi.org/10.1071/MF18391.

[50] Lieth H. Primary production of the major vegetation units of the world. In: Lieth $\mathrm{H}$, Whittaker RH, editors. Prim. Product. Biosph. Berlin: Springer-Verlag; 1975. p. 203-334. https://doi.org/10.1007/978-3-642-80913-2.

[51] Tonn B, Thumm U, Claupein W. Semi-natural grassland biomass for combustion: influence of botanical composition, harvest date and site conditions on fuel composition. Grass Forage Sci 2010;65:383-97. https://doi.org/10.1111/j.1365-2494. 2010.00758.x.

[52] Dwire KA, Kauffman JB, Brookshire ENJ, Baham JE. Plant biomass and species composition along an environmental gradient in montane riparian meadows. Oecologia 2004;139:309-17. https://doi.org/10.1007/s00442-004-1498-2.

[53] Karunaratne S, Asaeda T, Yutani K. Growth performance of Phragmites australis in Japan: influence of geographic gradient. Environ Exp Bot 2003;50:51-66https:// doi.org/10.1016/S0098-8472(02)00114-4.

[54] Kask Ü, Kask L, Link S. Combustion characteristics of reed and its suitability as a boiler fuel. Mires Peat 2013;13.

[55] Granéli W. Standing crop and mineral content of reed, Phragmites australis (Cav.) Trin. ex Steudel, in Sweden-Management of reed stands to maximize harvestable biomass. Folia Geobot Phytotaxon 1990;25:291-302. https://doi.org/10.1007/ BF02913030.

[56] Windham L. Comparison of biomass production and decomposition between Phragmites australis (common reed) and Spartina patens (salt hay grass) in brackish tidal marshes of New Jersey, USA. Wetlands 2006;21:179-88. https:// doi.org/10.1672/0277-5212(2001)021[0179:cobpad]2.0.co;2.

[57] Tanaka TST, Irbis C, Kumagai H, Inamura T. Timing of harvest of Phragmites australis (CAV.) Trin. ex Steudel affects subsequent canopy structure and nutritive value of roughage in subtropical highland. J Environ Manag 2016;166:420-8https://doi.org/10.1016/j.jenvman.2015.10.055.

[58] Eid EM, Shaltout KH, Al-Sodany YM, Soetaert K, Jensen K. Modeling growth, carbon allocation and nutrient budgets of Phragmites australis in lake burullus, Egypt. Wetlands 2010;30:240-51. https://doi.org/10.1007/s13157-010-0023-0.

[59] Opdekamp W, Beauchard O, Backx H, Franken F, Cox TJS, van Diggelen R, et al. Effects of mowing cessation and hydrology on plant trait distribution in natural fen meadows. Acta Oecol 2012;39:117-27https://doi.org/10.1016/j.actao.2012.01. 011.

[60] Zhou D, Luan Z, Guo X, Lou Y. Spatial distribution patterns of wetland plants in relation to environmental gradient in the Honghe National Nature Reserve, Northeast China. J Geogr Sci 2012;22:57-70. https://doi.org/10.1007/s11442012-0911-8.

[61] Wheeler BD, Proctor MCF. Ecological gradients, subdivisions and terminology of north-west European mires. J Ecol 2000;88:187-203. https://doi.org/10.1046/j. 1365-2745.2000.00455.x.

[62] Banaszuk P, Kamocki AK, Zarzecki R. Mowing with invasive machinery can affect chemistry and trophic state of rheophilous mire. Ecol Eng 2016;86:31-8https:// doi.org/10.1016/j.ecoleng.2015.10.005.

[63] Avellán T, Gremillion P. Constructed wetlands for resource recovery in developing countries. Renew Sustain Energy Rev 2019;99:42-57https://doi.org/10.1016/j. rser.2018.09.024.

[64] Heinsoo K, Hein K, Melts I, Holm B, Ivask M. Reed canary grass yield and fuel quality in Estonian farmers' fields. Biomass Bioenergy 2011;35:617-25. https:// doi.org/10.1016/j.biombioe.2010.10.022.

[65] Kukk L, Roostalu H, Suuster E, Rossner H, Shanskiy M, Astover A. Reed canary grass biomass yield and energy use efficiency in Northern European pedoclimatic conditions. Biomass Bioenergy 2011;35:4407-16. https://doi.org/10.1016/j biombioe.2011.08.018.

[66] Giannini V, Bertacchi A, Bonari E, Silvestri N. Rewetting in Mediterranean reclaimed peaty soils and its potential for phyto-treatment use. J Environ Manag 2018;208:92-101https://doi.org/10.1016/j.jenvman.2017.12.016.

[67] Middleton BA, Holsten B, van Diggelen R. Biodiversity management of fens and fen meadows by grazing, cutting and burning. Appl Veg Sci 2006;9:307-16. https:// doi.org/10.1111/j.1654-109X.2006.tb00680.x.

[68] Tälle M, Deák B, Poschlod P, Valkó O, Westerberg L, Milberg P. Grazing vs. mowing: a meta-analysis of biodiversity benefits for grassland management. Agric Ecosyst Environ 2016;222:200-12https://doi.org/10.1016/j.agee.2016.02.008.

[69] Merriam KE, Markwith SH, Coppoletta M. Livestock exclusion alters plant species composition in fen meadows. Appl Veg Sci 2018;21:3-11. https://doi.org/10. 1111/avsc. 12333.

[70] Kozub Ł, Goldstein K, Dembicz I, Wilk M, Wyszomirski T, Kotowski W. To mow or not to mow? Plant functional traits help to understand management impact on rich fen vegetation. Appl Veg Sci 2019;22:27-38. https://doi.org/10.1111/avsc.12411.

[71] Tälle M, Deák B, Poschlod P, Valkó O, Westerberg L, Milberg P. Similar effects of different mowing frequencies on the conservation value of semi-natural grasslands in Europe. Biodivers Conserv 2018;27:2451-75. https://doi.org/10.1007/s10531018-1562-6.

[72] Krause B, Culmsee H, Wesche K, Leuschner C. Historical and recent fragmentation of temperate floodplain grasslands: do patch size and distance affect the richness of characteristic wet meadow plant species? Folia Geobot 2015;50:253-66. https:// doi.org/10.1007/s12224-015-9220-1.

[73] Kołos A, Banaszuk P. Mowing may bring about vegetation change, but its effect is strongly modified by hydrological factors. Wetl Ecol Manag 2018;26:879-92. https://doi.org/10.1007/s11273-018-9615-x.

[74] Recchia L, Cini E, Corsi S. Multicriteria analysis to evaluate the energetic reuse of riparian vegetation. Appl Energy 2010;87:310-9. https://doi.org/10.1016/j. apenergy.2009.08.034.

[75] Shuai W, Chen N, Li B, Zhou D, Gao J. Life cycle assessment of common reed (Phragmites australis (Cav) Trin. ex Steud) cellulosic bioethanol in Jiangsu Province, China. Biomass Bioenergy 2016;92:40-7https://doi.org/10.1016/j. biombioe.2016.06.002.

[76] Giudice A, Assirelli A, Gallucci F, Bellacima R, Pari L, Santangelo E. Production of energy feedstock from the riparian vegetation of Arundo donax (L.). Suitability Chopping Syst. 2017;102. https://doi.org/10.1016/j.ecoleng.2017.01.040.

[77] Pahkala K, Pihala M. Different plant parts as raw material for fuel and pulp production. Ind Crops Prod 2000;11:119-28https://doi.org/10.1016/S09266690(99)00050-3.

[78] Iqbal Y, Lewandowski I. Lignocellulosic energy crops, production, and provision In: Meyers RA, editor. Encycl. Sustain. Sci. Technol. New York, NY: Springer New York; 2017. p. 1. https://doi.org/10.1007/978-1-4939-2493-6_319-4.

[79] Hadders G, Olsson R. Harvest of grass for combustion in late summer and in spring Biomass Bioenergy 1997;12:171-5https://doi.org/10.1016/S0961-9534(96) 00047-5.

[80] Ferrarini A, Serra P, Almagro M, Trevisan M, Amaducci S. Multiple ecosystem services provision and biomass logistics management in bioenergy buffers: a stateof-the-art review. Renew Sustain Energy Rev 2017;73:277-90https://doi.org/10. 1016/j.rser.2017.01.052.

[81] Dubowski AP, Zembrowski K, Rakowicz A, Pawlowski T, Weymann S, Wojnilowicz L. Developing new-generation machinery for vegetation management on protected wetlands in Poland. Mires Peat 2014;13:1-13.

[82] Schröder C, Dahms T, Paulitz J, Wichtmann W, Wichmann S. Towards large-scale paludiculture: addressing the challenges of biomass harvesting in wet and rewetted peatlands. vol. 16. 2015. p. 1-18.

[83] Bovolenta S, Spanghero M, Dovier S, Orlandi D, Clementel F. Chemical composition and net energy content of alpine pasture species during the grazing season. Anim Feed Sci Technol 2008;146:178-91. https://doi.org/10.1016/j.anifeedsci. 2008.06.003.

[84] King C, McEniry J, Richardson M, O'Kiely P. Yield and chemical composition of five common grassland species in response to nitrogen fertiliser application and phenological growth stage. Acta Agric Scand Sect B Soil Plant Sci 2012;62:644-58. https://doi.org/10.1080/09064710.2012.687055.

[85] Ren L, Eller F, Lambertini C, Guo WY, Brix H, Sorrell BK. Assessing nutrient responses and biomass quality for selection of appropriate paludiculture crops. Sci Total Environ 2019;664:1150-61. https://doi.org/10.1016/j.scitotenv.2019.01. 419.

[86] Melts I, Normak A, Nurk L, Heinsoo K. Chemical characteristics of biomass from nature conservation management for methane production. Bioresour Technol 2014;167:226-31. https://doi.org/10.1016/j.biortech.2014.06.009.

[87] Hensgen F, Bühle L, Donnison I, Frasier M, Vale J, Corton J, et al. Mineral concentrations in solid fuels from European semi-natural grasslands after hydrothermal conditioning and subsequent mechanical dehydration. Bioresour Technol 2012;118:332-42. https://doi.org/10.1016/j.biortech.2012.05.035.

[88] Herrmann C, Prochnow A, Heiermann M, Idler C. Biomass from landscape management of grassland used for biogas production: effects of harvest date and silage additives on feedstock quality and methane yield. Grass Forage Sci 2014;69:549-66. https://doi.org/10.1111/gfs.12086.

[89] Triolo JM, Pedersen L, Qu H, Sommer SG. Biochemical methane potential and anaerobic biodegradability of non-herbaceous and herbaceous phytomass in biogas production. Bioresour Technol 2012;125:226-32. https://doi.org/10.1016/ j.biortech.2012.08.079.

[90] Li Y, Zhang R, Liu G, Chen C, He Y, Liu X. Comparison of methane production potential, biodegradability, and kinetics of different organic substrates. Bioresour Technol 2013;149:565-9. https://doi.org/10.1016/j.biortech.2013.09.063.

[91] Amon T, Amon B, Kryvoruchko V, Machmüller A, Hopfner-Sixt K, Bodiroza V, et al. Methane production through anaerobic digestion of various energy crops grown in sustainable crop rotations. Bioresour Technol 2007;98:3204-12. https://doi.org/ 10.1016/j.biortech.2006.07.007.

[92] Pakarinen A, Kymalainen M, Stoddard FL, Viikari L. Conversion of carbohydrates in herbaceous crops during anaerobic digestion. J Agric Food Chem 2012;60:7934-40. https://doi.org/10.1021/jf301549b.

[93] Ong R, Bals B, Jasrotia P, Balan V, Dale B. Influence of variable species composition on the saccharification of AFEX (TM) pretreated biomass from unmanaged fields in comparison to corn stover. vol. 37. 2012. https://doi.org/10.1016/j biombioe.2011.12.036.

[94] Alvarez R, Lidén G. Anaerobic co-digestion of aquatic flora and quinoa with manures from Bolivian Altiplano. Waste Manag 2008;28:1933-40. https://doi. $\operatorname{org} / 10.1016 /$ j.wasman.2007.11.002.

[95] Friedl A, Padouvas E, Rotter H, Varmuza K. Prediction of heating values of biomas fuel from elemental composition. Anal Chim Acta 2005;544:191-8. https://doi org/10.1016/j.aca.2005.01.041.

[96] Cassida KA, Muir JP, Hussey MA, Read JC, Venuto BC, Ocumpaugh WR. Biofuel component concentrations and yields of switchgrass in south central U.S. environments. Crop Sci 2005;45:682-92.

[97] Jenkins BM, Baxter LL, Miles TR, Miles TR. Combustion properties of biomass. Fuel Process Technol 1998;54:17-46. https://doi.org/10.1016/S0378-3820(97) 
00059-3.

[98] Gren I-M, Söderqvist T, Wulff F. Nutrient reductions to the baltic sea: ecology, costs and benefits. J Environ Manag 1997;51:123-43https://doi.org/10.1006/ jema.1997.0137.

[99] Schoumans OF, Chardon WJ, Bechmann ME, Gascuel-Odoux C, Hofman G, Kronvang B, et al. Mitigation options to reduce phosphorus losses from the agricultural sector and improve surface water quality: a review. Sci Total Environ 2014;468-469:1255-66https://doi.org/10.1016/j.scitotenv.2013.08.061.

[100] Uwimana A, van Dam AA, Irvine K. Effects of conversion of wetlands to rice and fish farming on water quality in valley bottoms of the Migina catchment, southern Rwanda. Ecol Eng 2018;125:76-86https://doi.org/10.1016/j.ecoleng.2018.10. 019.

[101] Obernberger I, Brunner T, Bärnthaler G. Chemical properties of solid biofuelssignificance and impact. Biomass Bioenergy 2006;30:973-82. https://doi.org/10. 1016/j.biombioe.2006.06.011.

[102] El-Nashaar HM, Griffith SM, Steiner JJ, Banowetz GM. Mineral concentration in selected native temperate grasses with potential use as biofuel feedstock. Bioresour Technol 2009;100:3526-31https://doi.org/10.1016/j.biortech.2009. 02.051.

[103] AOAC. Official. Methods of analysis of the association of official analytical chemists. fifteenth ed. 1990. Arlington.

[104] Holmes W. Grass: its production and utilization. 2nd ed. British Grassland Society and Blackwell Scientific Publications; 1989.

[105] Köbbing JF, Thevs N, Zerbe S. The utilisation of reed (Phragmites australis): a review. Mires Peat 2013;13:1-14.

[106] Heinsoo K, Melts I, Sammul M, Holm B. The potential of Estonian semi-natural grasslands for bioenergy production. Agric Ecosyst Environ 2010;137:86-92. https://doi.org/10.1016/j.agee.2010.01.003.

[107] Melts I, Heinsoo K, Nurk L, Pärn L. Comparison of two different bioenergy production options from late harvested biomass of Estonian semi-natural grasslands. Energy 2013;61:6-12. https://doi.org/10.1016/j.energy.2013.06.016.

[108] Važić T, Svirčev Z, Dulić T, Krstić K, Obreht I. Potential for energy production from reed biomass in the Vojvodina region (north Serbia). Renew Sustain Energy Rev 2015;48:670-80. https://doi.org/10.1016/j.rser.2015.04.034.

[109] Corton J, Donnison IS, Patel M, Bühle L, Hodgson E, Wachendorf M, et al. Expanding the biomass resource: sustainable oil production via fast pyrolysis of low input high diversity biomass and the potential integration of thermochemical and biological conversion routes. Appl Energy 2016;177:852-62. https://doi.org/ 10.1016/j.apenergy.2016.05.088.

[110] Phillips D, Mitchell EJS, Lea-Langton AR, Parmar KR, Jones JM, Williams A. The use of conservation biomass feedstocks as potential bioenergy resources in the United Kingdom. Bioresour Technol 2016;212:271-9https://doi.org/10.1016/j. biortech.2016.04.057.

[111] Jones MB, Kansiime F, Saunders MJ. The potential use of papyrus (Cyperus papyrus L.) wetlands as a source of biomass energy for sub-Saharan Africa. GCB Bioenergy 2018;10:4-11. https://doi.org/10.1111/gcbb.12392.

[112] Van Meerbeek K, Ottoy S, de Andrés García M, Muys B, Hermy M. The bioenergy potential of Natura 2000 - a synergy between climate change mitigation and biodiversity protection. Front Ecol Environ 2016;14:473-8. https://doi.org/10. 1002/fee.1425.

[113] Meerbeek K Van, Muys B, Hermy M. Lignocellulosic biomass for bioenergy beyond intensive cropland and forests. Renew Sustain Energy Rev 2019;102:139-49https://doi.org/10.1016/j.rser.2018.12.009.

[114] McKendry P. Energy production from biomass (part 1): overview of biomass. Bioresour Technol 2002;83:37-46. https://doi.org/10.1016/S0960-8524(01) 00118-3.

[115] European Environmental Agency. EU bioenergy potential from a resource-efficiency perspective. Luxembourg. 2013. https://doi.org/10.2800/92247.

[116] Muazu A, Yahya A, Ishak WIW, Bejo SK. Machinery utilization and production cost of paddy cultivation under wetland direct seeding conditions in Malaysia. Eng Agric Environ Food 2015;8:289-97https://doi.org/10.1016/j.eaef.2015.03.007.

[117] Dalgaard T, Halberg N, Porter JR. A model for fossil energy use in Danish agriculture used to compare organic and conventional farming. Agric Ecosyst Environ 2001;87:51-65https://doi.org/10.1016/S0167-8809(00)00297-8.

[118] Haas G, Wetterich F, Köpke U. Comparing intensive, extensified and organic grassland farming in southern Germany by process life cycle assessment. Agric Ecosyst Environ 2001;83:43-53. https://doi.org/10.1016/S0167-8809(00) 00160-2.

[119] Wachendorf M, Büchter M, Trott H, Taube F. Performance and environmental effects of forage production on sandy soils. II. Impact of defoliation system and nitrogen input on nitrate leaching losses. Grass Forage Sci 2004;59:56-68. https:// doi.org/10.1111/j.1365-2494.2004.00401.x.

[120] Möller K, Müller T. Effects of anaerobic digestion on digestate nutrient availability and crop growth: a review. Eng Life Sci 2012;12:242-57. https://doi.org/10. 1002/elsc.201100085.

[121] Ward AJ, Hobbs PJ, Holliman PJ, Jones DL. Optimisation of the anaerobic digestion of agricultural resources. Bioresour Technol 2008;99:7928-40https://doi. org/10.1016/j.biortech.2008.02.044.

[122] Kaparaju P, Luostarinen S, Kalmari E, Kalmari J, Rintala J. Co-digestion of energy crops and industrial confectionery by-products with cow manure: batch-scale and farm-scale evaluation. Water Sci Technol 2002;45:275-80. https://doi.org/10. 2166/wst.2002.0352.

[123] Lehtomäki A, Viinikainen TA, Rintala JA. Screening boreal energy crops and crop residues for methane biofuel production. Biomass Bioenergy 2008;32:541-50https://doi.org/10.1016/j.biombioe.2007.11.013.

[124] Risén E, Gregeby E, Tatarchenko O, Blidberg E, Malmström ME, Welander U, et al.
Assessment of biomethane production from maritime common reed. J Clean Prod 2013;53:186-94. https://doi.org/10.1016/j.jclepro.2013.03.030.

[125] Jagadabhi PS, Kaparaju P, Rintala J. Two-stage anaerobic digestion of tomato, cucumber, common reed and grass silage in leach-bed reactors and upflow anaerobic sludge blanket reactors. Bioresour Technol 2011;102. https://doi.org/ 10.1016/j.biortech.2011.01.052. 4726-4233.

[126] Dragoni F, Giannini V, Ragaglini G, Bonari E, Silvestri N. Effect of harvest time and frequency on biomass quality and biomethane potential of common reed (Phragmites australis) under paludiculture conditions. Bioenergy Res 2017;10:1066-78. https://doi.org/10.1007/s12155-017-9866-z.

[127] Klimiuk E, Pokój T, Budzyński W, Dubis B. Theoretical and observed biogas production from plant biomass of different fibre contents. Bioresour Technol 2010;101:9527-35. https://doi.org/10.1016/j.biortech.2010.06.130.

[128] Rodriguez C, Alaswad A, Benyounis KY, Olabi AG. Pretreatment techniques used in biogas production from grass. Renew Sustain Energy Rev 2017;68:1193-204https://doi.org/10.1016/j.rser.2016.02.022.

[129] Prade T, Svensson SE, Andersson A, Mattsson JE. Biomass and energy yield of industrial hemp grown for biogas and solid fuel. Biomass Bioenergy 2011;35:3040-9. https://doi.org/10.1016/j.biombioe.2011.04.006.

[130] Van Meerbeek K, Appels L, Dewil R, Van Beek J, Bellings L, Liebert K, et al. Energy potential for combustion and anaerobic digestion of biomass from low-input highdiversity systems in conservation areas. GCB Bioenergy 2015;7:888-98. https:// doi.org/10.1111/gcbb.12208.

[131] Tutt M. Factors affecting biochemical composition of lignocellulosic biomass and its effect on selection of pretreatment method and on bioethanol production potential. 2015.

[132] Pakarinen A, Maijala P, Stoddard FL, Santanen A, Tuomainen P, Kymäläinen M, et al. Evaluation of annual bioenergy crops in the boreal zone for biogas and ethanol production. Biomass Bioenergy 2011;35:3071-8. https://doi.org/10. 1016/j.biombioe.2011.04.022.

[133] Ruiz HA, Rodríguez-Jasso RM, Fernandes BD, Vicente AA, Teixeira JA. Hydrothermal processing, as an alternative for upgrading agriculture residues and marine biomass according to the biorefinery concept: a review. Renew Sustain Energy Rev 2013;21:35-51https://doi.org/10.1016/j.rser.2012.11.069.

[134] Sun Y, Cheng J. Hydrolysis of lignocellulosic materials for ethanol production: a review. Bioresour Technol 2002;83:1-11https://doi.org/10.1016/S0960 8524(01)00212-7.

[135] Zabed HM, Akter S, Yun J, Zhang G, Awad FN, Qi X, et al. Recent advances in biological pretreatment of microalgae and lignocellulosic biomass for biofuel production. Renew Sustain Energy Rev 2019;105:105-28https://doi.org/10. 1016/j.rser.2019.01.048.

[136] FitzPatrick M, Champagne P, Cunningham MF, Whitney RA. A biorefinery processing perspective: treatment of lignocellulosic materials for the production of value-added products. Bioresour Technol 2010;101:8915-22https://doi.org/10 1016/j.biortech.2010.06.125.

[137] Naik SN, Goud VV, Rout PK, Dalai AK. Production of first and second generation biofuels: a comprehensive review. Renew Sustain Energy Rev 2010;14:578-97https://doi.org/10.1016/j.rser.2009.10.003.

[138] García V, Päkkilä J, Ojamo H, Muurinen E, Keiski RL. Challenges in biobutanol production: how to improve the efficiency? Renew Sustain Energy Rev 2011;15:964-80https://doi.org/10.1016/j.rser.2010.11.008.

[139] Budzianowski WM. High-value low-volume bioproducts coupled to bioenergies with potential to enhance business development of sustainable biorefineries. Renew Sustain Energy Rev 2017;70:793-804https://doi.org/10.1016/j.rser.2016. 11.260 .

[140] Hassan SS, Williams GA, Jaiswal AK. Moving towards the second generation of lignocellulosic biorefineries in the EU: drivers, challenges, and opportunities. Renew Sustain Energy Rev 2019;101:590-9https://doi.org/10.1016/j.rser.2018. 11.041.

[141] Tenorio AT, Kyriakopoulou KE, Suarez-Garcia E, van den Berg C, van der Goot AJ. Understanding differences in protein fractionation from conventional crops, and herbaceous and aquatic biomass - consequences for industrial use. Trends Food Sci Technol 2018;71:235-45https://doi.org/10.1016/j.tifs.2017.11.010.

[142] Grass S. Utilisation of grass for production of fibres, protein and energy. Biomass Agric. Sustain. Mark. Policies; 2004. https://doi.org/10.1787/ 9789264105546-en.

[143] Maity SK. Opportunities, recent trends and challenges of integrated biorefinery: Part I. Renew Sustain Energy Rev 2015;43:1427-45https://doi.org/10.1016/j. rser.2014.11.092.

[144] Parajuli R, Dalgaard T, Jørgensen U, Adamsen APS, Knudsen MT, Birkved M, et al. Biorefining in the prevailing energy and materials crisis: a review of sustainable pathways for biorefinery value chains and sustainability assessment methodologies. Renew Sustain Energy Rev 2015;43:244-63https://doi.org/10.1016/j.rser. 2014.11.041.

[145] Tang X, Wei J, Ding N, Sun Y, Zeng X, Hu L, et al. Chemoselective hydrogenation of biomass derived 5-hydroxymethylfurfural to diols: key intermediates for sustainable chemicals, materials and fuels. Renew Sustain Energy Rev 2017;77:287-96https://doi.org/10.1016/j.rser.2017.04.013

[146] Bühle L, Hensgen F, Donnison I, Heinsoo K, Wachendorf M. Life cycle assessment of the integrated generation of solid fuel and biogas from biomass (IFBB) in comparison to different energy recovery, animal-based and non-refining management systems. Bioresour Technol 2012;111:230-9https://doi.org/10.1016/j. biortech.2012.02.072.

[147] Bentsen NS, Møller IM. Solar energy conserved in biomass: sustainable bioenergy use and reduction of land use change. Renew Sustain Energy Rev 2017;71:954-8https://doi.org/10.1016/j.rser.2016.12.124. 
[148] Al-Battashi HS, Annamalai N, Sivakumar N, Al-Bahry S, Tripathi BN, Nguyen QD, et al. Lignocellulosic biomass (LCB): a potential alternative biorefinery feedstock for polyhydroxyalkanoates production. Rev Environ Sci Bio/Technology 2019;18:183-205. https://doi.org/10.1007/s11157-018-09488-4.

[149] Corato U De, Bari I De, Viola E, Pugliese M. Assessing the main opportunities of integrated biorefining from agro-bioenergy co/by-products and agroindustrial residues into high-value added products associated to some emerging markets: a review. Renew Sustain Energy Rev 2018;88:326-46https://doi.org/10.1016/j. rser.2018.02.041.

[150] Brix H, Ye S, Laws EA, Sun D, Li G, Ding X, et al. Large-scale management of common reed, Phragmites australis, for paper production: a case study from the Liaohe Delta, China. Ecol Eng 2014;73:760-9https://doi.org/10.1016/j.ecoleng. 2014.09.099.

[151] Fecka I. Qualitative and quantitative determination of hydrolysable tannins and other polyphenols in herbal products from meadowsweet and dog rose. Phytochem Anal 2009;20:177-90. https://doi.org/10.1002/pca.1113.

[152] Mărgăoan R, Zăhan M, Mărghitaș LA, Dezmirean DS, Erler S, Bobis O. Antiproliferative activity and apoptotic effects of Filipendula ulmaria pollen against C26 mice colon tumour cells. J Apic Sci 2016;60:135-44. https://doi.org/ 10.1515/jas-2016-0014.

[153] Arraki K, Totoson P, Decendit A, Badoc A, Zedet A, Jolibois J, et al. Cyperaceae species are potential sources of natural mammalian arginase inhibitors with positive effects on vascular function. J Nat Prod 2017;80:2432-8. https://doi.org/ 10.1021/acs.jnatprod.7b00197.

[154] Cui H, Pan H-W, Wang P-H, Yang X-D, Zhai W-C, Dong Y, et al. Essential oils from Carex meyeriana Kunth: optimization of hydrodistillation extraction by response surface methodology and evaluation of its antioxidant and antimicrobial activities. Ind Crops Prod 2018;124:669-76https://doi.org/10.1016/j.indcrop.2018.08.041.

[155] Kadlec RH, Wallace S. Treatment wetlands. 2nd ed. Boca Raton: Taylor \& Francis; 2008

[156] Worrall P, Peberdy KJ, Millett MC. Constructed wetlands and nature conservation. Water Sci Technol 1997;35:205-13https://doi.org/10.1016/S0273-1223(97) 00070-X.

[157] Vymazal J, Švehla J, Kröpfelová L, Chrastný V. Trace metals in Phragmites australis and Phalaris arundinacea growing in constructed and natural wetlands. Sci Total Environ 2007;380:154-62https://doi.org/10.1016/j.scitotenv.2007.01.057.

[158] Tee PF, Abdullah MO, Tan IAW, Rashid NKA, Amin MAM, Nolasco-Hipolito C, et al. Review on hybrid energy systems for wastewater treatment and bio-energy production. Renew Sustain Energy Rev 2016;54:235-46https://doi.org/10.1016/ j.rser.2015.10.011.
[159] Brix H. Do macrophytes play a role in constructed treatment wetlands? Water Sci Technol 1997;35:11-7https://doi.org/10.1016/S0273-1223(97)00047-4.

[160] Kekkonen H, Ojanen H, Haakana M, Latukka A, Regina K. Mapping of cultivated organic soils for targeting greenhouse gas mitigation. Carbon Manag 2019;0:1-12. https://doi.org/10.1080/17583004.2018.1557990.

[161] Schlattmann A, Rode M. Spatial potential for paludicultures to reduce agricultural greenhouse gas emissions: an analytic tool. vol. 25. 2019. p. 1-14. https://doi. org/10.19189/MaP.2017.OMB.324.

[162] Pienaar EF, Soto JR, Lai JH, Adams DC. Would county residents vote for an increase in their taxes to conserve native habitat and ecosystem services? Funding conservation in Palm Beach county, Florida. Ecol Econ 2019;159:24-34https:// doi.org/10.1016/j.ecolecon.2019.01.011.

[163] Casas F, Mougeot F, Viñuela J, Bretagnolle V. Effects of hunting on the behaviour and spatial distribution of farmland birds: importance of hunting-free refuges in agricultural areas. Anim Conserv 2009;12:346-54. https://doi.org/10.1111/j. 1469-1795.2009.00259.x.

[164] Daskalova GN, Phillimore AB, Bell M, Maggs HE, Perkins AJ. Population responses of farmland bird species to agri-environment schemes and land management options in Northeastern Scotland. J Appl Ecol 2019;56:640-50. https://doi.org/10. $1111 / 1365-2664.13309$.

[165] Kitazawa M, Yamaura Y, Senzaki M, Kawamura K, Hanioka M, Nakamura F. An evaluation of five agricultural habitat types for openland birds: abandoned farmland can have comparative values to undisturbed wetland. Ornithol Sci 2019;18:3. https://doi.org/10.2326/osj.18.3.

[166] McGinness HM, Arthur AD, Davies M. Flood regimes driving vegetation and bird community transitions in semiarid floodplain woodlands. Ecohydrology 2018;11:e1954. https://doi.org/10.1002/eco.1954.

[167] Vreš B, Seliškar A, Dakskobler I. The phytosociological position of Senecio fontanicola Grulich \& Hodálová, a rare and endangered species endemic to the Eastern Alps, in the successional sere on the montane wetland Zelenci (NW Slovenia). Wulfenia 2012;19:1-14.

[168] van Loon AH, Soomers H, Schot PP, Bierkens MFP, Griffioen J, Wassen MJ. Linking habitat suitability and seed dispersal models in order to analyse the effectiveness of hydrological fen restoration strategies. Biol Conserv 2011;144:1025-35https:// doi.org/10.1016/j.biocon.2010.12.021.

[169] Lienert J, Fischer M, Diemer M. Local extinctions of the wetland specialist Swertia perennis L. (Gentianaceae) in Switzerland: a revisitation study based on herbarium records. Biol Conserv 2002;103:65-76https://doi.org/10.1016/S0006-3207(01) 00121-5. 